\title{
Wound healing and plastic surgery - an introduction to a special issue
}

\author{
Raymund E. Horch \\ Department of Plastic and Hand Surgery, University Hospital Erlangen, Friedrich-Alexander University Erlangen-Nuernberg FAU, Erlangen \\ D-91054, Germany.
}

Correspondence to: Dr. Raymund E. Horch, Department of Plastic and Hand Surgery, University Hospital Erlangen, Friedrich-Alexander University Erlangen-Nuernberg FAU, Erlangen D-91054, Germany. E-mail: raymund.horch@uk-erlangen.de

How to cite this article: Horch RE. Wound healing and plastic surgery - an introduction to a special issue. Plast Aesthet Res 2018;5:42. http://dx.doi.org/10.20517/2347-9264.2018.64

Received: 8 Sep 2018 Accepted: 14 Sep 2018 Published: 19 Oct 2018

Science Editor: Raúl González-García Copy Editor: Cui Yu Production Editor: Zhong-Yu Guo

\section{INTRODUCTION}

"If I have seen further it is by standing on the shoulders of Giants." (Isaac Newton 1675) John of Salisbury attributed in 1159 the recognition to Bernard of Chartres who expressed that "we see more and farther than our predecessors, not because we have keener vision or greater height, but because we are lifted up and borne aloft on their gigantic stature." For reconstructive surgery - despite the brilliant innovations in recent times - this especially seems to hold true. Plastic surgery can proudly look back into an astonishing past and also into an even more fascinating future. Truly standing on the shoulder of giants constantly new ideas, techniques and materials have enriched our daily practice for the cure of our patients.

In addition whatever we do is somehow related to wound healing. Thus, the plastic surgeon is permanently confronted with all aspects of proper and disturbed wound healing on a daily basis.

In this issue a broad spectrum of topics related to wound healing shows the diversity of our specialty and highly renowned authors contribute on their experience with special problems of wound healing from different angles.

\section{SPECTRUM AND DEVELOPMENT OF PLASTIC SURGERY}

Plastic surgery is a specialty that dates back to ancient times as far as the descriptions of reconstructions of amputated noses with a frontal forehead flap mentioned in the Sushruta Samhita as early as 1500 B.C. The demand for nasal reconstructions (rhinoplasties) can be explained by the fact that amputation of the nose

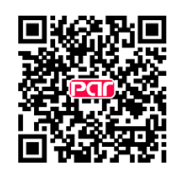


was a traditional punishment for various delicts. In western countries this technique remained unknown for long ${ }^{[1]}$. In Renaissance - probably due to the popularity of duelling with rapier - in the fifteenth, sixteenth and seventeenth centuries it was the Italian Branca family, who lived in 1400 in Catania, who were known to reconstruct amputated noses. They performed rhinoplasties utilizing random pattern skin flaps from the arm that were then transferred to the nose in several stages. A markstone in this regard was the book of the Italian surgeon Gaspare Tagliacozzi (1546-1599) "De curtorum chirurgia per insitionem libri duo" (Venice, 1597), who described the exact technique of this procedure along with various illustrations. However the method was more or less forgotten during the seventeenth century. It was rediscovered and revived by the German surgeon Karl Ferdinand von Graefe in 1800 , and hence was widely adopted ${ }^{[2]}$. Along with the evolution of very specialized surgical methods the development of surgical tools also helped to enhance plastic surgery techniques.

The initial breakthrough that sparked the rapid development of plastic surgery was a publication in the Gentleman's Magazine in October 1794 following its publication in the Indian Madras Gazette one year earlier, where a physician attached to the East India company named B.L. reported the steps of a nose reconstruction with the Indian forehead flap in detail along with a drawing of the technique. The methods were then taken up by a number of pioneering surgeons, such as Greafe and Dieffenbach for instance ${ }^{[2]}$. This eventually led to the application of various grafts, such as skin grafts and further popularization of advancement or rotational flaps.

Nevertheless for long random pattern flaps then remained the mainstay of plastic surgical reconstruction and the tedious and oftentimes uncomfortable course for the patients allowed the restoration of various acquired or inherited defects. Only when the principle of vascularized pedicled flaps, especially the (re-) invention of the latissums dorsi myocutaneous flap by Olivari became available another giant step was achieved that has been applied ever since for many indications ${ }^{[3]}$.

Because an ideal flap that would provide adequate shape, width, and length of well-vascularized tissues and would not come along with a donor site defect does not exist, the search for better solutions to help our patients has always driven further developments. More or less in the past decade, the so-called perforator flaps which rely on a vascular supply by a defined vascular pedicle rather than a vessel carrying muscle or fascia have tremendously helped to solve many coverage problems without sacrificing a muscle any longer. The advent of microsurgery allowed the transplantation of different types of tissue or various composite tissue flaps to be transposed to any remote recipient area, connecting the nourishing flap vessels to a vascular supply at the recipient site. Prefabrication and prelamination techniques ${ }^{[4,5]}$ have made possible that a customized replacement tissue is generated in the patient himself to fit into the desired defect ${ }^{[0,7]}$. Utilizing methods derived from tissue engineering with the help of arteriovenous loops have been shown to even reconstitute bone defects in the long term frame of up to 7 years ${ }^{[8]}$.

\section{Wound healing and plastic surgery}

Various highly acclaimed researchers and clinicians have contributed to the principles of wound healing and plastic surgery to bring a special issue together. Contributions include aspects of advanced free flap surgery using autologous extension grafts and bypasses for free flaps. Microsurgical free flaps together with bypass grafts or arteriovenous loops are discussed for extremely difficult-to-treat wounds as a last resort in specialized centers ${ }^{[9]}$.

Despite the advances of microsurgery in high-volume centers it remains to be discussed in which special situations certain pedicled flaps are indicated [Figure 1]. Although the era of microsurgery has broadened our spectrum tremendously, it is not the one and only solution for every indication. Therefore one article 

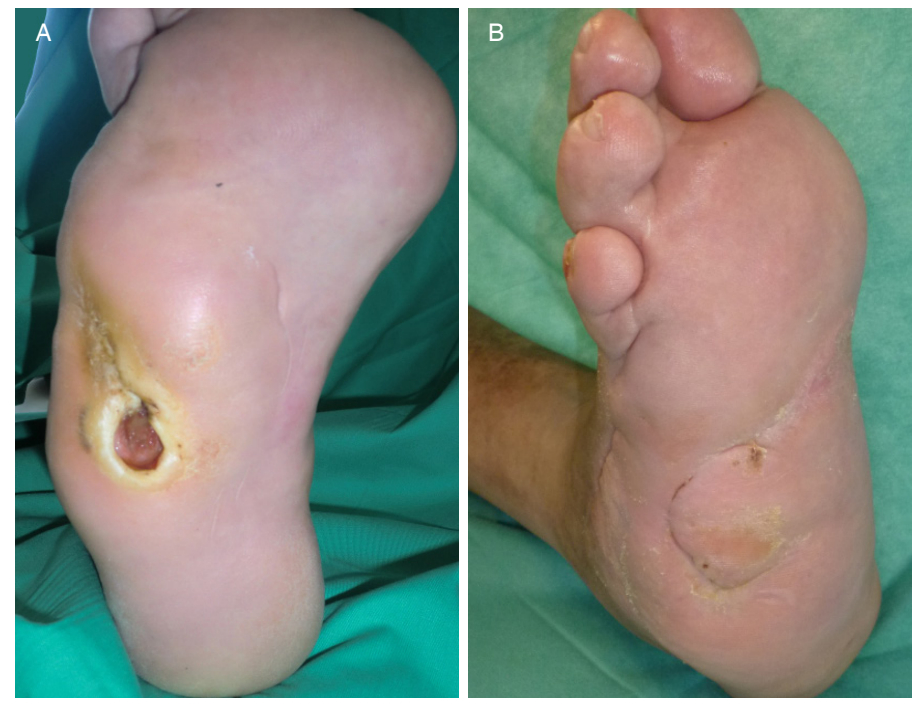

Figure 1. A: Sixty years old patient with typical diabetic foot ulcer, not responding to conservative therapy; B: complete healing of diabetic foot ulcer after surgical debridement, negative pressure wound therapy and transpositional flap from the sole of the foot with skin graft to the donor site

reflecting on pedicled flaps in the seldom event when free flaps may not be the first choice for various reasons ${ }^{[10,11]}$.

Techniques optimize results by remote ischemic tissue conditioning to reduce ischemia-reperfusion injury ${ }^{[12]}$.

Osteomyelitis as a typical problem wound is discussed by thoracic surgeons, as well as the worth of interdisciplinary approaches to cure extended sternoclavicular joint infections in cirrhotic patients ${ }^{[13]}$.

The value of negative pressure wound therapy with instillation (NPWTi) in pressure ulcers is described and the use of instillational therapy of infected wounds is discussed by a multi-institutional group of experts ${ }^{[14]}$. A very recent aspect of burn surgery is the advent of enzymatic debridement as an additional tool for wound healing and experts reflect on the state of the art in enzymatic debridement in burn patients ${ }^{[15,16]}$.

The specific problems of wound healing in postbariatric body contouring surgery are pointed out in a review that reflects the specific wound healing problems in this type of surgery ${ }^{[17]}$.

The recent knowledge about the role of adipose derived stem cells in cutaneous wound repair is highlighted with highly interesting results ${ }^{[1,19]}$. Wound healing mediated through the prefabrication of flaps and aspects of neoangiogenesis that is initiated via venous grafts in arteriovenous loops are one more outstanding contribution to the interaction of wound healing and plastic surgery ${ }^{[20-22]}$.

Given the various facettes of papers on wound healing and plastic surgery compiled in this special issue the compilation of original papers and reviews certainly is a unique demonstration of the enormously broad spectrum of current superb clinical and research knowledge in plastic surgery and wound healing. It covers important aspects of what is currently on the cutting edge in our specialty.

\section{CONCLUSION}

Because an ideal flap for all defects does not exist, each patient and defect must be evaluated separately to determine the best surgical approach. It turns out that today plastic surgical reconstruction is no more only 
tailored to the size or type of defect, but is rather tailored to the patient's individual needs. In addition the patient himself and his individual requirements need to be considered, especially when it comes to complex and stepwise reconstructions, such as prefabrication of customized flaps. Plastic surgeons can now choose from a variety of reconstructive modalities with a broad armamentarium of techniques. In all apsects we must not forget that the basic principles of wound healing play an essential role during every apsect of plastic and aesthetic surgery.

\section{DECLARATIONS}

\section{Authors' contributions}

The author contributed solely to the article.

\section{Availability of data and materials}

Not applicable.

\section{Financial support and sponsorship}

None.

\section{Conflicts of interest}

The author declared that there are no conflicts of interest.

\section{Ethical approval and consent to participate}

All our patients sign a consent form at the time of admission that they are informed that any photos may be used for scientific purposes and publication.

\section{Consent for publication}

Not applicable.

\section{Copyright}

(c) The Author(s) 2018.

\section{REFERENCES}

1. Keil G. The history of plastic surgery (author's transl). Laryngol Rhinol Otol (Stuttg) 1978;57:581-91.

2. Mazzola RF, Marcus S. History of total nasal reconstruction with particular emphasis on the folded forehead flap technique. Plast Reconstr Surg 1983;72:408-14.

3. Olivari N. The latissimus flap. Br J Plast Surg 1976;29:126-8.

4. Schipper J, Leffler M, Maier W, Kopp J, Bach AD, et al. Reconstruction of tumor induced defects in head and neck surgery with individualized prefabricated three dimensional flaps with the use of continuous vacuum therapy. Zentralbl Chir 2006;131:S141-5. (in German)

5. Pribaz JJ, Fine NA. Prelamination: defining the prefabricated flap--a case report and review. Microsurgery 1994;15:618-23.

6. Schipper J, Ridder GJ, Maier W, Teszler CB, Horch RE. Laryngotracheal reconstruction using prefabricated and preconditioned composite radial forearm free flaps. A report of two cases. Auris Nasus Larynx 2007;34:253-8.

7. Schipper J, Ridder GJ, Maier W, Horch RE. The preconditioning and prelamination of pedicled and free microvascular anastomised flaps with the technique of vacuum assisted closure. Laryngorhinootologie 2003;82:421-7. (in German)

8. Horch RE, Beier JP, Kneser U, Arkudas A. Successful human long-term application of in situ bone tissue engineering. J Cell Mol Med 2014;18:1478-85.

9. Arkudas A, Horch RE, Regus S, Meyer A, Lang W, et al. Retrospective cohort study of combined approach for trunk reconstruction using arteriovenous loops and free flaps. J Plast Reconstr Aesthet Surg 2018;71:394-401.

10. Kneser U, Brockmann S, Leffler M, Haeberle L, Beier JP, et al. Comparison between distally based peroneus brevis and sural flaps for reconstruction of foot, ankle and distal lower leg: an analysis of donor-site morbidity and clinical outcome. J Plast Reconstr Aesthet Surg 2011;64:656-62.

11. Bach AD, Leffler M, Kneser U, Kopp J, Horch RE. The versatility of the distally based peroneus brevis muscle flap in reconstructive surgery of the foot and lower leg. Ann Plast Surg 2007;58:397-404.

12. Kolbenschlag J, Sogorski A, Harati K, Daigeler A, Wiebalck A, et al. Upper extremity ischemia is superior to lower extremity ischemia 
for remote ischemic conditioning of antero-lateral thigh cutaneous blood flow. Microsurgery 2015;35:211-7.

13. Dudek W, Schreiner W, Horch RE, Sirbu H. Sternal resection and reconstruction for secondary malignancies. J Thorac Dis 2018;10:42305.

14. Erba P, Rieger UM, Pierer G, Kalbermatten DF. Vacuum-assisted closure (VAC) for venous congestion of the nipple-areola complex. J Plast Reconstr Aesthet Surg 2008;61:852-4.

15. Hirche C, Citterio A, Hoeksema H, Koller J, Lehner M, et al. Eschar removal by bromelain based enzymatic debridement (Nexobrid $($ ) in burns: an European consensus. Burns 2017;43:1640-53.

16. Cordts T, Horter J, Vogelpohl J, Kremer T, Kneser U, et al. Enzymatic debridement for the treatment of severely burned upper extremities early single center experiences. BMC Dermatol 2016;16:8.

17. Dragu A, Horch RE. Concept of reconstructive body shaping in obesity. Evidence-based therapy algorithm. Chirurg 2014;85:37-41. (in German)

18. Robering JW, Weigand A, Pfuhlmann R, Horch RE, Beier JP, et al. Mesenchymal stem cells promote lymphangiogenic properties of lymphatic endothelial cells. J Cell Mol Med 2018; doi: 10.1111/jcmm.13590.

19. Ruhl T, Kim BS, Beier JP. Cannabidiol restores differentiation capacity of LPS exposed adipose tissue mesenchymal stromal cells. Exp Cell Res 2018;370:653-62.

20. Schmidt VJ, Covi JM, Koepple C, Hilgert JG, Polykandriotis E, et al. Flow induced microvascular network formation of therapeutic relevant arteriovenous (AV) loop-based constructs in response to ionizing radiation. Med Sci Monit 2017;23:834-42.

21. Weigand A, Beier JP, Arkudas A, Al-Abboodi M, Polykandriotis E, et al. The arteriovenous (AV) loop in a small animal model to study angiogenesis and vascularized tissue engineering. J Vis Exp 2016; doi: 10.3791/54676.

22. Polykandriotis E, Arkudas A, Euler S, Beier JP, Horch RE, et al. Prevascularisation strategies in tissue engineering. Handchir Mikrochir Plast Chir 2006;38: 217-23. (in German) 